\title{
GMR
}

\section{A glimpse of the endophytic bacterial diversity in roots of blackberry plants (Rubus fruticosus)}

\author{
M. Contreras ${ }^{1}$, P.D. Loeza ${ }^{2}$, J. Villegas ${ }^{1}$, R. Farias ${ }^{1}$ and G. Santoyo ${ }^{1}$ \\ ${ }^{1}$ Instituto de Investigaciones Químico Biológicas, \\ Universidad Michoacana de San Nicolás de Hidalgo, Morelia, Michoacán, \\ México \\ ${ }^{2}$ Genómica Alimentaria, \\ Universidad de La Ciénega del Estado de Michoacán de Ocampo, Sahuayo, \\ Michoacán, México \\ Corresponding author: R. Farias \\ E-mail: rodolfofarias44@yahoo.com.mx
}

Genet. Mol. Res. 15 (3): gmr. 15038542

Received February 11, 2016

Accepted April 15, 2016

Published September 16, 2016

DOI http://dx.doi.org/10.4238/gmr.15038542

Copyright $(\odot 2016$ The Authors. This is an open-access article distributed under the terms of the Creative Commons Attribution ShareAlike (CC BY-SA) 4.0 License.

\begin{abstract}
The aim of this study was to explore the diversity of culturable bacterial communities residing in blackberry plants (Rubus fruticosus). Bacterial endophytes were isolated from plant roots, and their 16S rDNA sequences were amplified and sequenced. Our results show that the roots of $R$. fruticosus exhibit low colony forming units of bacterial endophytes per gram of fresh tissue $\left(6 \times 10^{2} \pm 0.5\right.$ x $10^{2}$ ). We identified 41 endophytic bacterial species in $R$. fruticosus by BLAST homology search and a subsequent phylogenetic analysis, belonging to the classes Actinobacteria, Bacilli, Alfaproteobacteria, Betaproteobacteria, and Gammaproteobacteria. Predominantly, genera belonging the Proteobacteria (Burkholderia, 29.4\%; Herbaspirillum, 10.7\%; Pseudomonas, 4.9\%; and Dyella, 3.9\%), Firmicutes (Bacillus, 42.1\%), and Actinobacteria (two isolates showing high identity with
\end{abstract}

Genetics and Molecular Research 15 (3): gmr.15038542 
the Streptomyces genus, 1.9\%) divisions were identified. Fifty percent of the bacterial endophytes produced the phytohormone indole-acetic acid (IAA), eleven of which exhibited higher IAA production $(>5.8$ $\mu \mathrm{g} / \mathrm{mL}$ ) compared to the plant growth-promoting strain, Pseudomonas fluorescens UM270. Additionally, the endophytic isolates exhibited protease activity (22\%), produced siderophores (26.4\%), and demonstrated antagonistic action ( $>50 \%$ inhibition of mycelial growth) against the grey mold phytopathogen Botrytis cinerea (3.9\%). These results suggested that field-grown $R$. fruticosus plants contain bacterial endophytes within their tissues with the potential to promote plant growth and display antagonism towards plant pathogens.

Key words: Bacterial endophytes; Diversity; Fungal antagonism; Plant growth-promotion mechanisms

\section{INTRODUCTION}

Endophytic bacteria are bacterial species that live within plant tissues innocuously (Kado, 1992), and can be isolated from surface-disinfested plant tissue or extracted from within plants that have not been visibly harmed by the endophyte (Hallman et al., 1997). Some authors have suggested that the efficiency of interaction of bacterial endophytes with their plant hosts is greater than that of rizhospheric bacteria (Ali et al., 2014). The rhizosphere is inhabited by many potential bacterial endophytes, as this ecosystem closely interacts with plant roots, the main entry pathway into plant tissues; however, seed-endophytes, which are vertically transferred do not inhabit the rhizosphere (Truyens et al., 2015). Primary and lateral root cracks, as well as diverse tissue wounds resulting from plant growth, allow rhizospheric bacteria to penetrate and colonize the internal tissues of plants (Ali et al., 2014; Santoyo et al., 2016). Therefore, the rhizosphere is recognized as a reservoir of potential bacterial endophytes (Márquez-Santacruz et al., 2010).

Several studies have documented the benefits of bacterial endophytic growth within plant tissues (Santoyo et al., 2016). For example, bacterial endophytes promote growth in, and render protection against pathogenic infections to, their host plants. Moreover, bacterial endophytes have been shown to induce resistance mechanisms in plants growing under diverse environmental stress conditions (Sziderics et al., 2007; Doty et al., 2009; Ali et al., 2014; Morais-Braga et al., 2015). Previous studies have documented the various direct and indirect mechanisms employed by bacterial endophytes to promote plant growth (Glick, 2014; Santoyo et al., 2016). Sessitsch et al. (2005) reported that ACC deaminase, secreted by the endophytic bacteria Burkholderia phytofirmans PsJN, played a direct role in promoting plant growth. However, mutants with ACC deaminase activity, constructed by Sun et al. (2009), were unable to promote root elongation in canola seedlings. Other well-studied endophytes, such as Azoarcus sp or Gluconacetobacter diazotrophicus, are also involved in promoting growth in diverse plant species, by fixing nitrogen within the plant tissues (Krause et al., 2006; Lery et al., 2011). Other direct mechanisms of plant growth promotion include the production of indole-acetic acid (IAA), siderophores, hydrogen cyanide, and proteases, and indirect mechanisms include the biocontrol of plant pathogens (Santoyo et al., 2012).

The first step towards documenting the beneficial properties and functions of bacterial endophytes is analyzing its diversity. So far, every plant analyzed around the world has been

Genetics and Molecular Research 15 (3): gmr.15038542 
shown to contain bacterial endophytes. Proteobacteria belonging to the classes $\alpha, \beta$, and $\gamma$, as well as species belonging to the classes Actinobacteria and Firmicutes, are some of the most predominant endophytes. Bacterial species belonging to other classes, such as Acidobacteria, Bacteroidetes, Planctomycetes, and Verrucomicrobia are less commonly found in plant tissues. Bacillus, Pseudomonas, Burkholderia, Stenotrophomonas, Micrococcus, Pantoea, and Microbacterium are among the most abundant and commonly reported genera of plant endophytes (Hallman et al., 1997; Márquez-Santacruz et al., 2010; Friesen et al., 2011; Xiong et al., 2014).

In this study, the diversity of bacterial communities residing in the roots of Rubus fruticosus (blackberry) plants from Los Reyes, Michoacán, México was characterized by $16 \mathrm{~S}$ rDNA sequencing. Los Reyes is a major producer of blackberries (and other berries), exporting $80 \%$ of the total produce to countries such as USA, Canada, Spain, and Germany (SAGARPA, 2015). However, $R$. fruticosus plants cultivated in the Los Reyes region are commonly exposed to unfavorable environmental conditions, such as a lack of soil nutrients and pathogen attacks, which can reduce its production and affect the economy. As the use of agrochemicals affects fruit export, there is an urgent need for the development of eco-friendly inoculants to promote plant growth and health, as well as to control the $R$. fruticosus pathogens.

\section{MATERIAL AND METHODS}

\section{Plant sampling and bacterial isolation}

Endophytic bacteria were isolated from 24 R. fruticosus plants grown in an agricultural field in Los Reyes, Michoacán, México (1959'00"N 102 $17^{\circ} 00^{\prime \prime O}$, altitude: 1580 m.a.s.1.); the (approximately) two-month old, randomly-selected plants were donated by the farm owners and transported to the lab for analysis. The roots were washed with sterile distilled water and strongly adhered soil particles were carefully removed manually. Root tissue (1 g) specimens were obtained from each plant and surface sterilized using a method described by MárquezSantacruz et al. (2010). Briefly, the roots were immersed in 70\% ethanol for $30 \mathrm{~s}$, washed with fresh sodium hypochlorite solution $\left(2.5 \%\right.$ available $\left.\mathrm{Cl}^{-}\right)$for $5 \mathrm{~min}$, rinsed with $70 \%$ ethanol for $30 \mathrm{~s}$, and finally washed five times with sterile distilled water. To further confirm the success of the sterilization process, aliquots of the sterile distilled water used in the final rinse were cultured on plates containing NA medium. The plates were examined for bacterial growth after incubation at $28^{\circ} \mathrm{C}$ for 4 days. Uncontaminated roots, as detected by a culture-dependent sterility test, were used for the isolation of endophytic bacteria.

\section{Molecular characterization of isolates}

Genomic DNA was isolated from 102 bacterial isolates, and their 16S rDNA subunits were subjected to PCR for further DNA sequencing, using the bacterial primers fD1 (5'-CAGAGTTTGATCCTGGCTCAG-3') and rD1 (5'-AAGGAGGTGATCCAGCC-3') (Weisburg et al., 1991). Previously reported PCR conditions were applied (Márquez-Santacruz et al., 2010). All PCR products were purified and directly sequenced at LANGEBIO (Irapuato, Mexico). The obtained rDNA sequences were subjected to homology searches against sequences uploaded to biological databases using the Basic Local Alignment Search Tool (BLAST); the obtained sequences were subsequently deposited to GenBank (accession Nos.: KP634900-KP635001).

Genetics and Molecular Research 15 (3): gmr.15038542 


\section{Phylogenetic analysis}

Multiple sequence alignments were generated and the 16S rDNA gene sequences were phylogenetically analyzed using MEGA 5.0 (Tamura et al., 2011). All sequences passed the quality control tests. A confidence value for the aligned sequence dataset was obtained by performing a bootstrap analysis of 1000 replications. A phylogenetic tree was constructed using the maximum likelihood algorithm.

\section{Identification of fungal antagonism and plant-growth promotion determinants}

The isolated strains were analyzed for diverse plant growth-promotion traits. Skim milk agar plates were used to detect protease production (Kumar et al., 2005) and siderophore production was determined by the chrome azurol S assay (Alexander and Zuberer, 1991). Indole-3-acetic acid (IAA) production was analyzed as previously reported by HernándezLeón et al. (2015), using gas chromatography-mass spectrometry (Gas Chromatograph 6850 Series II - Mass Spectrometry detector 5973; Agilent, Foster City, CA, USA) analysis. IAA production was confirmed by comparing the retention time in the bacterial extracts against that of pure IAA standard samples (Sigma-Aldrich, St. Louis, MO, USA). The IAA amounts produced by the bacterial isolates were estimated using calibration curves.

In vitro evaluation for fungal antagonism was evaluated using a method previously reported by Santoyo et al. (2010). Bacterial isolates were simultaneously deposited with pathogenic fungi on either PDA or NA agar plates, with very similar results in both media. Bacteria were streaked on plates in a cross shape, and a 4-mm mycelial plug was deposited at the center of each of the quadrants. The plates were incubated in a biological oxygen demand incubator in the dark at $30^{\circ} \mathrm{C}$, and the mycelial growth diameter was measured at day 6 . Strains showing $>50 \%$ mycelial growth were considered as antagonists. All experiments described in this section were performed in triplicate.

\section{RESULTS}

\section{Abundance of culturable bacterial endophytes}

In this study, we followed a culturable method to isolate bacterial endophytes with a potential role in plant protection and growth promotion. Unexpectedly, our analysis revealed that the roots of $R$. fruticosus plants exhibited low colony forming units (CFUs) of endophytic bacteria (low abundance) per gram of tissue $\left(6 \times 10^{2} \pm 0.5 \times 10^{2}\right)$.

\section{Diversity and phylogenetic analysis of bacterial endophytes}

Bacterial colonies were randomly picked for $16 \mathrm{~S}$ rDNA sequencing, in order to obtain a representative sample of the culturable diversity of bacterial endophytes inhabiting the roots of $R$. fruticosus. Forty-one different bacterial endophytic species or operational taxonomic units were identified by a BLAST homology search. These bacterial endophytes belonged to 5 classes: Actinobacteria, Bacilli, Alfaproteobacteria, Betaproteobacteria, and Gammaproteobacteria (Figure 1). The genus Bacillus (42.1\%), belonging to the Firmicutes division, was the most commonly detected and the most abundant endophyte in the roots of $R$. fruticosus plants. Additionally, we

Genetics and Molecular Research 15 (3): gmr.15038542 
observed multiple genera belonging to the division Proteobacteria, including Burkholderia (29.4\%), Herbaspirillum (10.7\%), Pseudomonas (4.9\%) and Dyella (3.9\%). Two isolates showed high 16S rDNA gene identity with the Streptomyces genus (1.9\%), belonging to the division Actinobacteria. Analysis of the bacterial endophyte diversity at the species and genus level revealed that Bacillus cereus was most commonly isolated from $R$. fruticosus roots (Figure 1). Herbaspirillum frisingense, Lysinibacillus sphaericus, Burkholderia sp, Bacillus tropica, Bacillus phytofirmans, and Bacillus caledonica were also among the most abundant isolates.

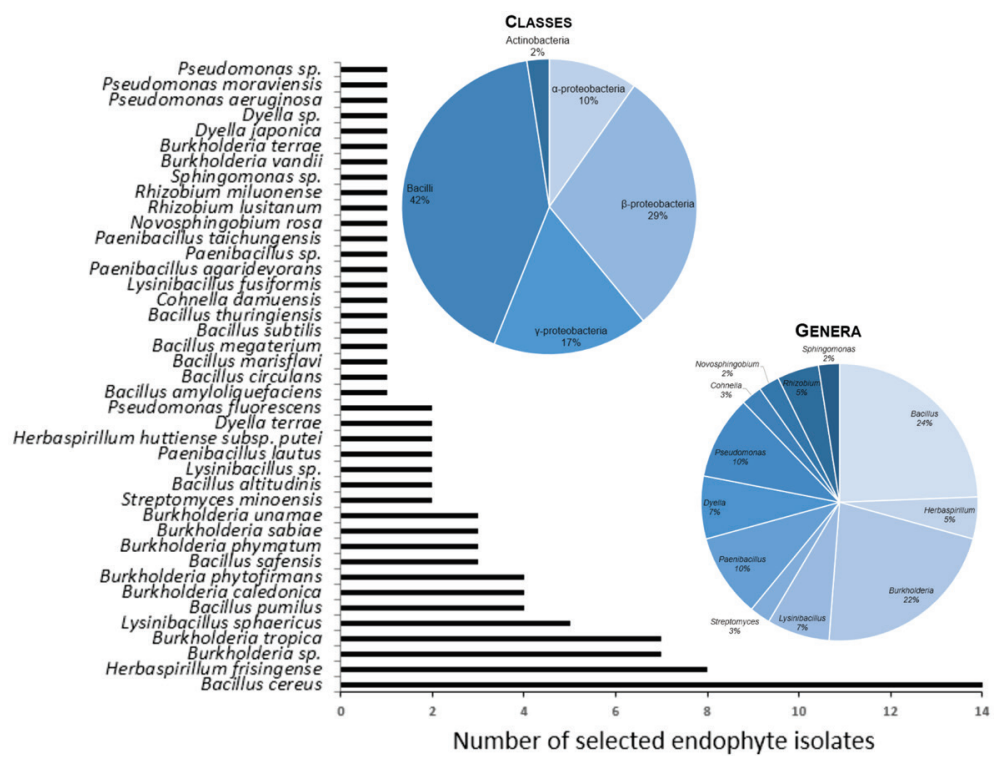

Figure 1. Diversity of bacterial endophytes isolated from roots of blackberry plants (Rubus fruticosus). Pie graphs represent the distribution of bacterial classes and genera in percentages.

Figure 2 shows the phylogenetic relationships of bacterial endophytes isolated from $R$. fruticosus roots. The phylogenetic tree includes 102 endophyte isolates that are representative of the 5 classes identified in this study (Actinobacteria, Bacilli, Alfaproteobacteria, Betaproteobacteria, and Gammaproteobacteria). All sequenced 16S rDNA samples were closely related to known bacterial species, with identities $>97 \%$ in sequence alignment analysis.

\section{Potential mechanisms of plant protection and growth promotion}

In this study, the potential mechanisms of plant growth-promotion and phytopathogen inhibition were also explored, in order to assign preliminary functional roles to the plant bacterial endophytes. Figure 3 shows that $50 \%$ of the isolated bacterial endophytes produced the phytohormone IAA; however, eleven of these produced higher quantities of IAA $(>5.8$ $\mu \mathrm{g} / \mathrm{mL}$ ) than the plant growth-promoting strain, Pseudomonas fluorescens UM270. The endophytic isolates also exhibited protease activity (22\%), siderophore production (26.4\%), and antagonistic action ( $>50 \%$ mycelial growth inhibition) against the grey mold phytopathogen Botrytis cinerea $(3.9 \%)$. In this study, we selected the most promising bacterial endophytes for further analysis of plant growth promotion in greenhouse and field experiments.

Genetics and Molecular Research 15 (3): gmr.15038542 


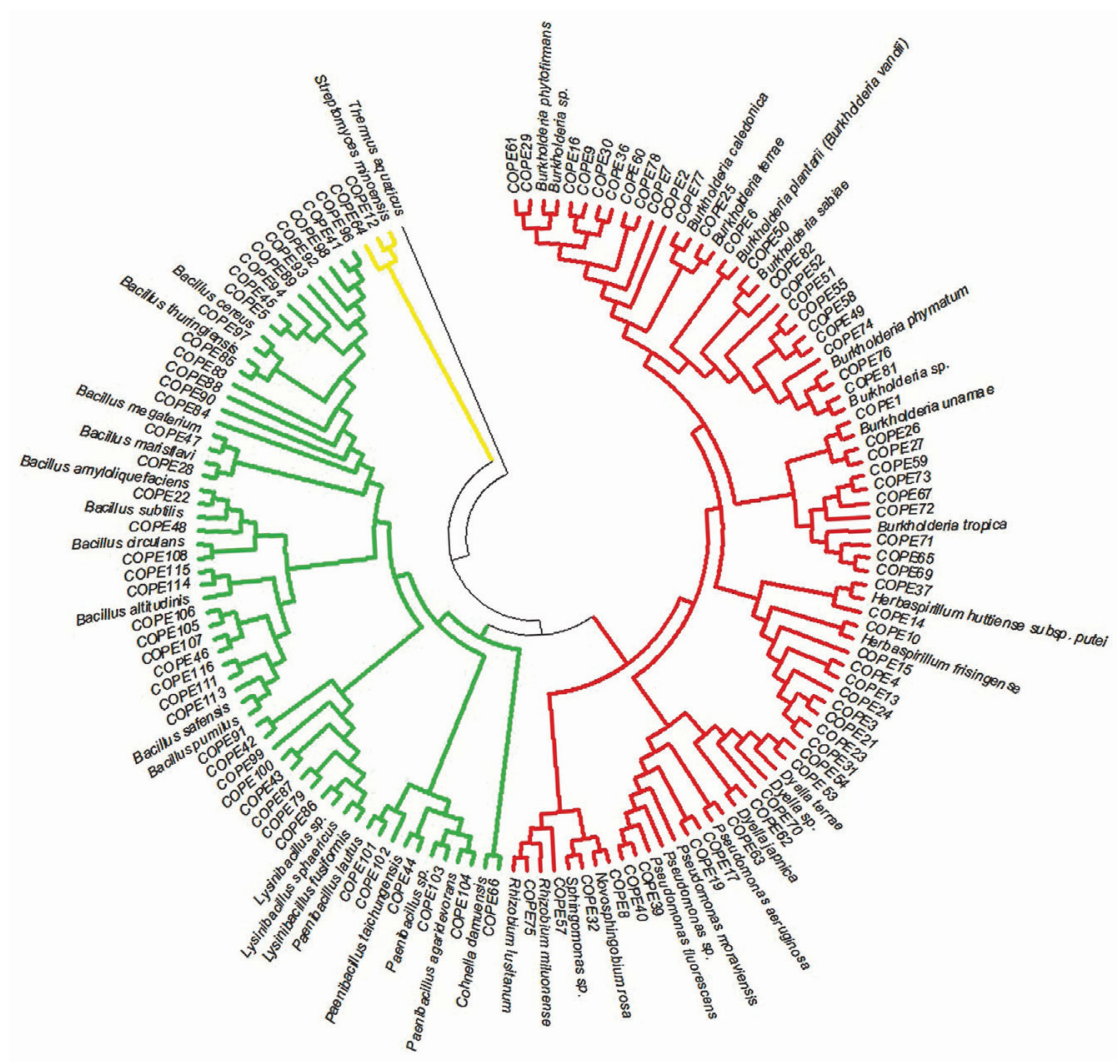

Figure 2. Phylogenetic tree based on 16S rDNA gene analysis of the endophytic bacterial community inhabiting the roots of Rubus fruticosus plants. The method used for analysis is detailed in the Material and Methods section.

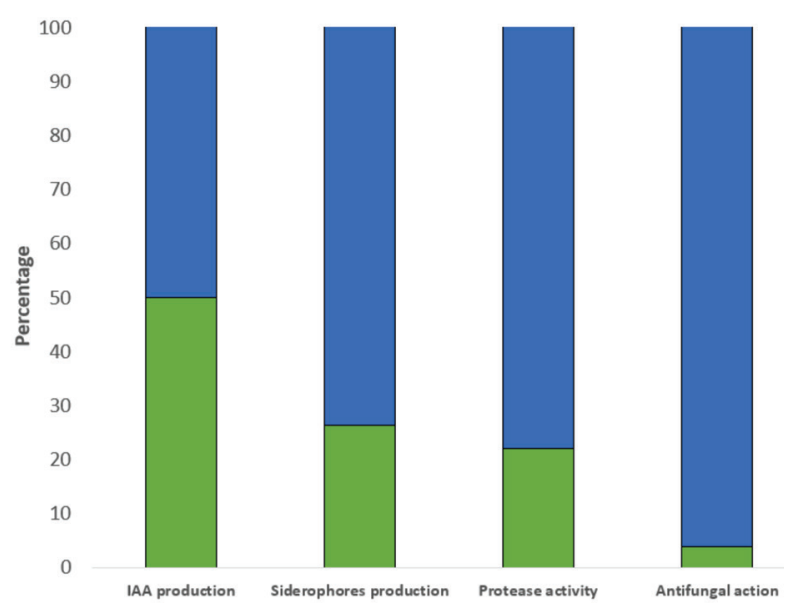

Figure 3. Percentage distribution of the potential antifungal and direct plant growth-promoting mechanisms of endophytic bacteria (green color), such as the production of indole-acetic acid (IAA), synthesis of siderophores, protease activity, and antifungal activity against the grey mold phytopathogen Botrytis cinerea. 


\section{DISCUSSION}

Blackberry plants (R. fruticosus) belong to the Rosaceae family of shrubs, characterized by woody stems and angular thorns that are tender in youth. This could be responsible for the low degree of colonization by endophytic bacteria living in the rhizosphere (Santoyo et al., 2016), as the number of bacterial endophytes found in this study is low compared to the numbers seen in studies conducted in other plants with a higher percentage of soft tissue. For example, Germaine et al. (2004) reported the presence of $10^{2}-10^{4} \mathrm{CFU}$ endophytes per gram of poplar plant tissue. Studies conducted in other plants with high percentages of soft tissue, such as rice (Gyaneshwar et al., 2001), citrus plants (Araújo et al., 2002), and sugarcane (Mendes et al., 2007), have also reported an abundance of endophyte colonization $\left(10^{2}-10^{3} \mathrm{CFU} / \mathrm{g}\right.$ rice tissue, $10^{2}-10^{4} \mathrm{CFU} / \mathrm{g}$ citrus plant root tissue, and $10^{2}-10^{6} \mathrm{CFU} / \mathrm{g}$ sugarcane tissue). The abundance of bacterial endophytes within plant tissues is reported to be directly proportional to the biological effect exerted on the host plants. Mendes et al. (2011) reported that the Pseudomonas phylotype, a component of the microbial consortia growing in suppressive soils, is an important suppressor of diseases caused by Rhizoctonia solani in these soils. This is an interesting hypothesis that must be tested on bacterial endophytes in their plant hosts. Moreover, the abundance of bacterial endophytes inhabiting the internal tissues of plants may be variable and dependent on several factors, such as the species, stage of growth, or type of tissue analyzed (Santoyo et al., 2016). As the rhizosphere is one of the main reservoirs of potential endophytes, it could be hypothesized that soils with poor microbial and bacterial diversity could have a lower capacity and endophyte abundance required to colonize plant roots.

In this study, we analyzed the culturable bacteria inhabiting the internal roots of $R$. fruticosus growing in the field. This analysis provides us with a glimpse of the endophytic diversity and its potential role in promoting antifungal activity and plant growth. A majority of the bacterial species isolated from blackberry roots in this study belong to the Bacillus species, followed by the Burkholderia species, a close relative of the Pseudomonas species. Members of the Bacillus, Pseudomonas, and Burkholderia genera have been widely recognized by their biocontrol and plant growth-promoting activities (Santoyo et al., 2012). These species produce a number of metabolites with a wide range of functions and applications, such as antibiotics, volatile organic compounds, and antifungal, antiviral, and insecticidal compounds (Ryan et al., 2008; Martínez-Absalón et al., 2014). These three genera have also been detected as endophytes in the roots of Mexican husk tomato plants (Physalis ixocarpa Brot.) by MárquezSantacruz et al. (2010), and as regular microbiota in many other plant hosts (Li et al., 2015; Ludwig-Müller, 2015; Sheibani-Tezerji et al., 2015).

Species belonging to the Herbaspirillum genus are also abundantly and commonly found as endophytes in $R$. fruticosus plants. Previous reports have identified this genus as a common endophyte of Oryza sativa and other gramineous plants (Rothballer et al., 2008). Recently, Zgadzaj et al. (2015) co-inoculated endophytic Herbaspirillum strains and the natural symbiont Mesorhizobium loti to lotus plants. Interestingly, both species were shown to efficiently colonize the nodules formed by infecting $M$. loti symbionts. Additionally, several bacterial consortia were co-inoculated to test the colonization capacity of $L$. japonicus plant nodules. The results of this revealed complex and interesting host-microbe and microbemicrobe interactions, demonstrating the possibility of expanding the available strategy for improving plant growth using nitrogen-fixing bacteria along with other bacterial endophytes (Zgadzaj et al., 2015). The Dyella genus, a previously reported plant endophyte, was not very

Genetics and Molecular Research 15 (3): gmr.15038542 
abundant in blackberry roots, despite being among the most represented genera in the roots of Cytisus striatus (Becerra-Castro et al., 2011). Interestingly, the latter results were obtained in C. striatus plants growing at a hexachlorocyclohexane-contaminated site that were analyzed for their bacterial endophyte diversity. Interestingly, Dyella strains are capable of producing IAA and biosurfactant products, suggesting their potential role in plant growth-promotion and phytoremediation.

A recent review on plant growth-promoting bacterial endophytes by Santoyo et al. (2016) analyzed the diverse and similar mechanisms employed by plant growth-promoting Rhizobacteria (PGPR), such as the production of phytohormones like auxin, cytokinin, gibberellin, IAA, acetoin, and 2,3-butanediol, iron-chelating compounds such as siderophores, and protease activity. Indirect promotion of plant growth occurs when a PGPR avoids infection with a phytopathogen, such as fungi or bacteria. In this study, both direct and indirect mechanisms were detected in the bacterial endophytes isolated from the $R$. fruticosus root tissues. Therefore, we expect to identify both protective and growth promoting mechanisms in future experiments with the selected endophytes.

The biodiversity of endophytic bacteria has been studied in various host plants of agricultural importance, such as peppers (Marasco et al., 2012), maize (Stamford et al., 2002), potatoes (Andreote et al., 2010), and tomatoes (Márquez-Santacruz et al., 2010). However, their features and functional roles can be diverse. We propose that the search for novel bacterial endophytes may help identify novel mechanisms that benefit plant growth, and reveal interesting interactions between plants and their endophytes, and between endophyte strains within the plant.

\section{Conflicts of interest}

The authors declare no conflict of interest.

\section{ACKNOWLEDGMENTS}

We would like to thank Coordinación de la Investigación Científica-Universidad Michoacana de San Nicolás de Hidalgo (\#2014-2015) (G. Santoyo and R. Farias) and CONACYT-México (scholarship to M. Contreras) for the financial support provided.

\section{REFERENCES}

Alexander DB and Zuberer DA (1991). Use of chrome azurol S reagents to evaluate siderophore production by rhizosphere bacteria. Biol. Fertil. Soils 12: 39-45. http://dx.doi.org/10.1007/BF00369386

Ali S, Charles TC and Glick BR (2014). Amelioration of high salinity stress damage by plant growth-promoting bacterial endophytes that contain ACC deaminase. Plant Physiol. Biochem. 80: 160-167. http://dx.doi.org/10.1016/j. plaphy.2014.04.003

Andreote FD, da Rocha UN, Araújo WL, Azevedo JL, et al. (2010). Effect of bacterial inoculation, plant genotype and developmental stage on root-associated and endophytic bacterial communities in potato (Solanum tuberosum). Antonie van Leeuwenhoek 97: 389-399. http://dx.doi.org/10.1007/s10482-010-9421-9

Araújo WL, Marcon J, Maccheroni W, van Elsas JD, et al. (2002). Diversity of endophytic bacterial populations and their interaction with Xylella fastidiosa in citrus plants. Appl. Environ. Microbiol. 68: 4906-4914. http://dx.doi. org/10.1128/AEM.68.10.4906-4914.2002

Becerra-Castro C, Kidd PS, Prieto-Fernández Á, Weyens N, et al. (2011). Endophytic and rhizoplane bacteria associated with Cytisus striatus growing on hexachlorocyclohexane-contaminated soil: isolation and characterisation. Plant Soil 340: 413-433. http://dx.doi.org/10.1007/s11104-010-0613-x

Genetics and Molecular Research 15 (3): gmr.15038542 
Doty SL, Oakley B, Xin G, Kang J, et al. (2009). Diazotrophic endophytes of native black cottonwood and willow. Symbiosis 47: 23-33. http://dx.doi.org/10.1007/BF03179967.

Friesen ML, Porter SS, Stark SC, von Wettberg EJ, et al. (2011). Microbially mediated plant functional traits. Annu. Rev. Ecol. Evol. Syst. 42: 23-46. http://dx.doi.org/10.1146/annurev-ecolsys-102710-145039

Germaine K, Keogh E, Garcia-Cabellos G, Borremans B, et al. (2004). Colonization of poplar trees by gfp expressing bacterial endophytes. FEMS Microbiol. Ecol. 48: 109-118.http://dx.doi.org/10.1016/j.femsec.2003.12.009

Glick BR (2014). Bacteria with ACC deaminase can promote plant growth and help to feed the world. Microbiol. Res. (Pavia) 169: 30-39.http://dx.doi.org/10.1016/j.micres.2013.09.009

Gyaneshwar P, James EK, Mathan N, Reddy PM, et al. (2001). Endophytic colonization of rice by a diazotrophic strain of Serratia marcescens. J. Bacteriol. 183: 2634-2645. http://dx.doi.org/10.1128/JB.183.8.2634-2645.2001

Hallman J, Quadt-Hallman A, Mahaffee WF and Kloepper JW (1997). Bacterial endophytes in agricultural crops. Can. J. Microbiol. 43: 895-914. http://dx.doi.org/10.1139/m97-131

Hernández-León R, Rojas-Solís D, Contreras-Pérez M, Orozco-Mosqueda MC, et al. (2015). Characterization of the antifungal and plant growth-promoting effects of diffusible and volatile organic compounds produced by Pseudomonas fluorescens strains. Biol. Control 81: 83-92. http://dx.doi.org/10.1016/j.biocontrol.2014.11.011

Kado CI (1992). Plant pathogenic bacteria. In: The Prokaryotes (Balows A, Truper HG, Dworkin M, Harder W, et al., eds.) Springer Science, New York, 659-674.

Krause A, Ramakumar A, Bartels D, Battistoni F, et al. (2006). Complete genome of the mutualistic, N2-fixing grass endophyte Azoarcus sp. strain BH72. Nat. Biotechnol. 24.

Kumar S, Sharma NS, Saharan MR and Singh R (2005). Extracellular acid protease from Rhizopus oryzae: purification and characterization. Process Biochem 40: 1701-1705. http://dx.doi.org/10.1016/j.procbio.2004.06.047

Lery LM, Hemerly AS, Nogueira EM, von Krüger WM, et al. (2011). Quantitative proteomic analysis of the interaction between the endophytic plant-growth-promoting bacterium Gluconacetobacter diazotrophicus and sugarcane. Mol. Plant Microbe Interact. 24: 562-576. http://dx.doi.org/10.1094/MPMI-08-10-0178

Li H, Dietrich C, Zhu N, Mikaelyan A, et al. (2015). Age polyethism drives community structure of the bacterial gut microbiota in the fungus-cultivating termite Odontotermes formosanus. Environ. Microbiol.

Ludwig-Müller J (2015). Plants and endophytes: equal partners in secondary metabolite production? Biotechnol. Lett. 37: 1325-1334.http://dx.doi.org/10.1007/s10529-015-1814-4

Marasco R, Rolli E, Ettoumi B, Vigani G, et al. (2012). A drought resistance-promoting microbiome is selected by root system under desert farming. PLoS One 7: e48479. http://dx.doi.org/10.1371/journal.pone.0048479

Márquez-Santacruz HA, Hernandez-Leon R, Orozco-Mosqueda MC, Velazquez-Sepulveda I, et al. (2010). Diversity of bacterial endophytes in roots of Mexican husk tomato plants (Physalis ixocarpa) and their detection in the rhizosphere. Genet. Mol. Res. 9: 2372-2380. http://dx.doi.org/10.4238/vol9-4gmr921

Martínez-Absalón S, Rojas-Solís D, Hernández-León R, Prieto-Barajas C, et al. (2014). Potential use and mode of action of the new strain Bacillus thuringiensis UM96 for the biological control of the grey mould phytopathogen Botrytis cinerea. Biocontrol Sci. Technol. 24: 1349-1362. http://dx.doi.org/10.1080/09583157.2014.940846

Mendes R, Pizzirani-Kleiner AA, Araujo WL and Raaijmakers JM (2007). Diversity of cultivated endophytic bacteria from sugarcane: genetic and biochemical characterization of Burkholderia cepacia complex isolates. Appl. Environ. Microbiol. 73: 7259-7267. http://dx.doi.org/10.1128/AEM.01222-07

Mendes R, Kruijt M, de Bruijn I, Dekkers E, et al. (2011). Deciphering the rhizosphere microbiome for disease-suppressive bacteria. Science 332: 1097-1100. http://dx.doi.org/10.1126/science.1203980

Morais-Braga MF, Souza TM, Santos KK, Guedes GM, et al. (2015). Additive effect of Lygodium venustum SW. in association with gentamicin. Nat. Prod. Res. 1-3.http://dx.doi.org/10.1080/14786419.2015.1074227

Rothballer M, Eckert B, Schmid M, Fekete A, et al. (2008). Endophytic root colonization of gramineous plants by Herbaspirillum frisingense. FEMS Microbiol. Ecol. 66: 85-95. http://dx.doi.org/10.1111/j.1574-6941.2008.00582.x

Ryan RP, Germaine K, Franks A, Ryan DJ, et al. (2008). Bacterial endophytes: recent developments and applications. FEMS Microbiol. Lett. 278: 1-9.http://dx.doi.org/10.1111/j.1574-6968.2007.00918.x

SAGARPA (Secretaría de Agricultura, Ganadería Desarrollo Rural, Pesca y Alimentación) (2015). Annual Report. SAGARPA, México.

Santoyo G, Valencia-Cantero E, Orozco-Mosqueda MC, Peña-Cabriales JJ, et al. (2010). Papel de los sideróforos en la actividad antagónica de Pseudomonas fluorescens zum80 hacia hongos fitopatógenos [Role of siderophores in antagonistic activity of Pseudomonas fluorescens zum80 against phytopatogens]. Terra Latinoam. 28: 53-60.

Santoyo G, Orozco-Mosqueda MC and Govindappa M (2012). Mechanisms of biocontrol and plant growth-promoting activity in soil bacterial species of Bacillus and Pseudomonas: a review. Biocontrol. Sci. Technol. 22: 855-872. http:// dx.doi.org/10.1080/09583157.2012.694413

Genetics and Molecular Research 15 (3): gmr.15038542 
Santoyo G, Moreno-Hagelsieb G, Orozco-Mosqueda MC and Glick BR (2016). Plant growth-promoting bacterial endophytes. Microbiol. Res. 183: 92-99. http://dx.doi.org/10.1016/j.micres.2015.11.008

Sessitsch A, Coenye T, Sturz AV, Vandamme P, et al. (2005). Burkholderia phytofirmans sp. nov., a novel plant-associated bacterium with plant-beneficial properties. Int. J. Syst. Evol. Microbiol. 55: 1187-1192. http://dx.doi.org/10.1099/ ijs. $0.63149-0$

Sheibani-Tezerji R, Rattei T, Sessitsch A, Trognitz F, et al. (2015). Transcriptome profiling of the endophyte Burkholderia phytofirmans PsJN indicates sensing of the plant environment and drought stress. MBio 6: e00621-15.http://dx.doi. org/10.1128/mBio.00621-15

Stamford TLM, Stamford NP, Coelho LCBB and Araujo JM (2002). Production and characterization of a thermostable glucoamylase from Streptosporangium sp. endophyte of maize leaves. Bioresour. Technol. 83: 105-109. http://dx.doi. org/10.1016/S0960-8524(01)00206-1

Sun Y, Cheng Z and Glick BR (2009). The presence of a 1-aminocyclopropane-1-carboxylate (ACC) deaminase deletion mutation alters the physiology of the endophytic plant growth-promoting bacterium Burkholderia phytofirmans PsJN. FEMS Microbiol. Lett. 296: 131-136. http://dx.doi.org/10.1111/j.1574-6968.2009.01625.x

Sziderics AH, Rasche F, Trognitz F, Sessitsch A, et al. (2007). Bacterial endophytes contribute to abiotic stress adaptation in pepper plants (Capsicum annuum L.) Can. J. Microbiol. 53: 1195-1202. http://dx.doi.org/10.1139/W07-082

Tamura K, Peterson D, Peterson N, Stecher G, et al. (2011). MEGA5: molecular evolutionary genetics analysis using maximum likelihood, evolutionary distance, and maximum parsimony methods. Mol. Biol. Evol. 28: 2731-2739. http://dx.doi.org/10.1093/molbev/msr121

Truyens S, Weyens N, Cuypers A and Vangronsveld J (2015). Bacterial seed endophytes: genera, vertical transmission and interaction with plants. Environ. Microbiol. Rep. 7: 40-50. http://dx.doi.org/10.1111/1758-2229.12181

Weisburg WG, Barns SM, Pelletier DA and Lane DJ (1991). 16S ribosomal DNA amplification for phylogenetic study. $J$. Bacteriol. 173: 697-703.

Xiong XQ, Liao HD, Ma JS, Liu XM, et al. (2014). Isolation of a rice endophytic bacterium, Pantoea sp. Sd-1, with ligninolytic activity and characterization of its rice straw degradation ability. Lett. Appl. Microbiol. 58: 123-129. http://dx.doi.org/10.1111/lam.12163

Zgadzaj R, James EK, Kelly S, Kawaharada Y, et al. (2015). A legume genetic framework controls infection of nodules by symbiotic and endophytic bacteria. PLoS Genet. 11: e1005280. http://dx.doi.org/10.1371/journal.pgen.1005280

Genetics and Molecular Research 15 (3): gmr.15038542 